\title{
Lecturers' Adaptability To Technological Change And Its Impact On The Teaching Process
}

\author{
Harisa Mardiana ${ }^{1}$ \\ ${ }^{1}$ Study Program Informatics Engineering, Faculty of Science and Technology, \\ Universitas Buddhi Dharma, Indonesia \\ Email: soehanadiharisa@gmail.com
}

\begin{abstract}
The purpose of the research is to investigate the lecturers' adaptability to technological change and its impact on the teaching process. To adapt the technological change, lecturers must have attitudes to learn technology, knowledge in technology, ability, and skills to change them into qualified lecturers. The problem in Tangerang City is the lecturers have difficulty in adapting the technology, some of the lecturers unprepared in teaching and make the learning chaotic. Other lectures give many tasks and quizzes the same as the classroom's learning, and it will not achieve the learning goal. The research method is mixed methods, and the primary data is from questionnaires that give to the lecturers by Google Form. Data collection measures in 2 dimensions of lecturers' adaptability and online teaching. The result found that 85 respondents can adapt to technological change, and for the use of online teaching, there were 87 respondents. Some of the lecturers tried to move to online teaching and learn advanced techniques. And with this research, it was shown that lecturers were ready to move to the 21-century online learning process.
\end{abstract}

Keywords: Lecturers' Adaptability; Advanced Technology; Teaching Online; Learning Outcomes

\section{Introduction}

The development of face-to-face learning in the classroom until now has shown rapid progress. Current education tends to be in a computer lab; students use laptops and listen to lecturer lectures using podcasts (Banks, 2017). The use of technology in learning has become a trend in the 21 st century. Technology provides opportunities for lecturers that can collaborate and expand learning outside the classroom. In class, communities consisting of students and lecturers which offer access to teaching materials as well as resources and tools to create, manage, and assess their quality and usefulness ( South \& Stevens, 2017). In adapting to technological change, lecturers must have a flexible attitude and skills in increasing technical knowledge so that the diffusion of learning technology can be applied and sustainable ( Pionke, 2018). Lecturers who are supported by the campus in accessing technology can learn how to use technology effectively.

Moreover, lecturers have a significant impact on student learning and are responsible for bringing technology-based learning (Mardiana, 2018). Technological changes in education have created new ways to learn and learn. Students and lecturers bring their computers to study. Hence, lecturers must adopt a unique teaching methodology, and students follow a new style of learning. Changes in technology enable lecturers to access information on a global scale through the Internet to improve their learning, and students use Internet resources to enrich learning experiences (Banks, 2017). University should take the actions (technology policy, lecturer recruitment plan, and faculty restructuring). It means that change must start from class to class, with each lecturer personally adjusting the way they learn. So it requires efforts to become part of the lecturers because they must educate in new skills before continuing the learning knowledge (Boyd, 2014). In reality, many lecturers in Indonesia cannot adopt the latest technology of teaching. In pandemic Covid-19, the learning process is mostly online learning. The unpreparedness of lecturers in teaching online makes the learning chaotic ( Lederman, 2020). On the other side, the efforts to advance education using technology have been conveyed by Indonesia Ministry Nadiem Makarim, which stated that the use of 
technology is a necessity in school, but the contribution of educational technology platforms to the education system is still declared inadequate (Soegiono, 2019). As the interview with some students, they protest because learning did not work correctly.

Some many tasks and quizzes do not need to give to students to make student work pile up and not complete. Lecturers give online learning the same as providing knowledge in the classroom, even though the assignment should give in phased online learning. Students spend a lot of money doing tasks resulting in learning costs charged to students ( Adit, 2020); ( Matas \& Cameron, 2005). What needs in teaching by using technology is to have the right targets or by using teaching and learning methodologies that tailors and affordable, impressive (Hayes, 2017)? In the previous research by Howard \& Mozejko (2015) stated that institutional policies, curriculum, and changes in digital technology in the classroom make lecturers have to change the way they teach. In assigning tasks must be following the online curriculum of the institution or campus. Lecturers involved in online learning must demonstrate learning that is different from in the classroom. Another research by Ertmer \& Otenbreit-Leftwich (2010) stated that assist lecturers in online teaching, an institution or campus must facilitate meaningful learning that enables students to build deeper and connected knowledge that applies to real situations. Therefore, online teaching can work well by adopting new approaches in teaching and changing the content or context of learning. Groff (2013) mentioned that apart from being a resource, technology can play a role as the primary key holder in the learning element. The power to change teaching by introducing a new model that connects lecturers and students with content, resources, and professional systems that enhance their teaching (Hamiti \& Reka, 2012). Based on the researchers above, this research concluded that lecturers' adaptability in technological change is a process that includes the ability and skills in the use of technology that has an open-source on the Internet that can share learning content and involve institutions or campuses and students.

The purpose of this research is to find the lecturers' adaptability to technological change in the learning process and to describe five indicators for each dimension. For lecturers' adaptability, the five indicators are improving the teaching skills, and technology makes easy life; the lecturers should have belief, lecturers should have the ability and skill of technology; lecturers should have training. For a technological change, the five indicators are the use of technology in teaching, the use of the Internet and social media, sharing and contributing the contents, digital literacy, and learning from other lecturers or experts from the Internet. With those indicators, the lecturers can adapt to the technology to pursue teaching online and five indicators that the use of technology will help the lecturers provide online teaching and improve their knowledge of technology. With the lecturers' adaptability to technological change, the online teaching process will run smoothly.

\section{Literature Review}

The purpose of education is to meet the quality of student and lecturer learning experiences. By using advanced technology, content development, and increasing technological awareness, the quality of learning continues to increase (Collie, Martin, \& Granziera, 2018). Furthermore, changes in the way students learn and how to teach lecturers in delivering lessons affect the learning process. Lecturers and students who adapt to these changes can be motivated, have the support of technological change, increase knowledge, and trust in technology to support the sustainability of the learning process (McMichael, 2018).

The technological abilities and skills are changing rapidly; bringing the development of education can be achieved. Changes in learning begin with curriculum and pedagogical from traditional face-to-face to online teaching (Bergmann \& Brough, 2007). The problem faced is 
the lack of motivation for lecturers and campus leaders to learn more deeply using technology patterns is a resistant factor. The institution or campus must be able to provide a learning environment and critical leadership competencies used as one of the practical strategies implemented in the organization (Cohen, Fetters, \& Fleischmann, 2005).

The utilization of technology is not just a list of tasks from an institutional leader. Still, a commitment to promote the sustainability of learning and technology adaptation is needed and becomes an academic priority (Alamsyah, 2018). In education, unpreparedness with the conditions of rapid technological change shows the inability to be oriented towards information flow. Teachers consider the use of technology as a barrier in a career (Lü, 2018). Although the university has provided training and technology tools, many lecturers are unable and unskilled to use the tools. Many have said that older lecturers have difficulty adapting to technology. Still, after searching for more approval, lecturers who are young and not old have difficulty adapting to technology. They are already in the comfort zone, they are neglectful in increasing their knowledge. This becomes a big problem if the lecturer ignores their ability to increase their knowledge.

Research from the Scottish Government (2015) stated that as a progressive process, lecturers need to adapt technology with adequate knowledge, abilities, and skills. Technological change integrates new teaching methodologies in the form of online teaching and is introduced to students to use in the learning process. Another researcher Chapman D. W (2004), indicated that the move to advanced technology has enormous implications on teacher training, the pedagogical strategies they use, how the curriculum is structured, and how schools utilize their budget. The implication may ripple through the systems. In some cases, the move of instructional use of technology can create digital divides such as unintentional disparities in learning in different levels of access to the technology. In adopting technology-based delivery may broaden the access, but it will raise questions about controlling the instructional content ( Gaižiūnienè, 2019); (Mählck \& Chapman, 2004).

By teaching online, lecturers may have an easier life, because it is flexible hours and have the discussion. The discussion in teaching online with the increased depth and quality of student and lecturer responses offers unique advantages compared to the classroom ( Roblyer, Porter, \& Bielefeldt, 2009 ). Online discussion can be attended by many people and many experts so that with the presence of experts, the presence of lecturers will be easier, and there is no need to answer specific questions one by one. Also, there is an increase in communication with instructors with good and polite discussion patterns. It also educates students to communicate well ( Bakia, Shear, Toyama, \& Lasseter, 2012). Another researcher Rice (2006) found out that online teaching strategies made use of the online environment's unique potential when discussions were very interactive and based on Meta-analyses that compared learning achievements. Another point is lecturers must move to know about technology, beliefs, and training. The training will be doing by campuses or other places with the ability and skills (Banks, 2017).

Collaborative learning in universities using technology emphasizes several aspects of learning. Many challenges and directions of learning are associated with methodological and empirical evidence. The need for collaborative learning in an online social context will strengthen the values and skills needed for the university environment (Ertmer \& OttenbreitLeftwich, 2010). In lecturers' collaboration, a lot of quality feedback delivered will help students in opening gaps in knowledge and skills. Thus allowing lecturers to make different assignments for each student that depends on their needs, students can ask questions or ask other lecturers about the learning and overall student progress (Hayes, 2017). 
A strong collaborative environment can go beyond classroom learning and can invite experts to provide advice as well as opinions or theories about learning. For online professional improvement and development, lecturers can easily exchange ideas and heard by students. It can inspire them in lifelong learning and build cooperation in the future (Boyd, 2014). By using collaborative tools available at universities, students and lecturers can share documents online, edit them in real-time and project directly on the screen. And this gives an example to students that collaboration platforms can brainstorm ideas and document their work using text and images ( Bogdan-Martin, 2019). Besides that, lecturers can use technology and features to interact with other lecturers or with students, and this opportunity can use to share learning content and ways of teaching. So that lecturers can develop and add deeper knowledge (Dalkir, 2005). And, with training, lecturers can learn to share content. By having good pedagogical potential, learning content can use for many lecturers, and knowledge and teaching skills will increase, and create confidence in the lecturer (Killion, 2015).

\section{Method}

The method of the research is mixed-methods, which showed on the quantitative and qualitative methods. The source of data collection for this research consists of primary data sources that take from the questionnaires is made on Google Form that is spread to 116 lecturers via Facebook, E-mail, WhatsApp and other social media in October 2019-January 2020. The use of the quantitative method and qualitative method consists of the testing theory by investigation of variable the lecturers' adaptability to technological change (Cresswell, 2014). Data for the independent (predictor) variables used 2 questions, which dimension of lecturers' adaptability, online teaching. Regarding the dependent (outcome) variables is lecturers' adaptability to technological change.

\subsection{Framework of Research}

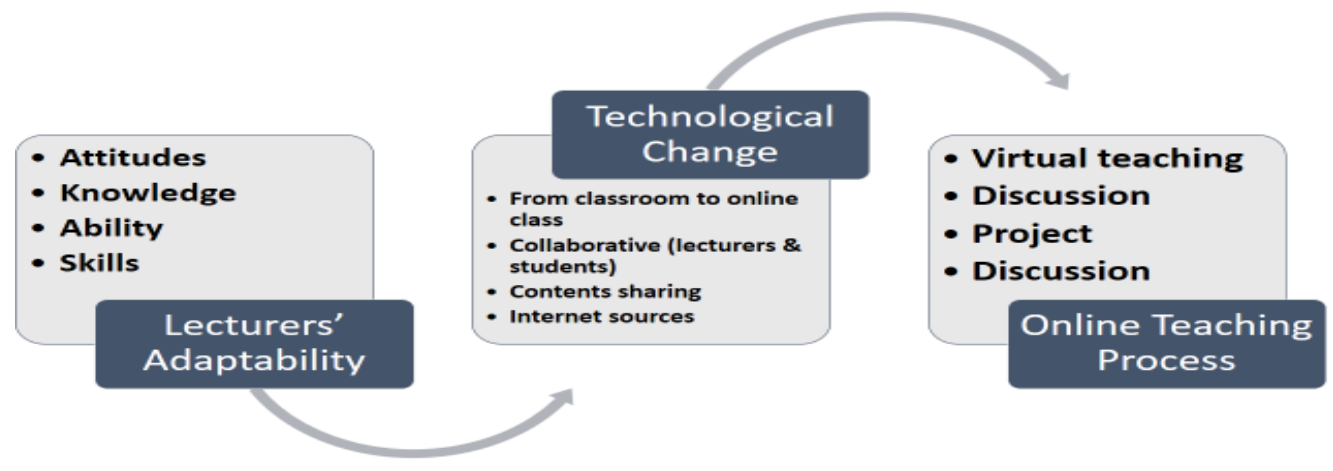

Figure 1. Framework of Research

\subsection{Hypothesis}

1. There is a statistically significant relationship between lecturers adaptability as the dependent variable with independent variable technological change $(\mathrm{H} 1)$

2. There is a statistical relationship between technological change as an independent variable with the online teaching process $(\mathrm{H} 2)$

3. There are statistically relationship among lecturers' adaptability as a dependent variable, technological change as an independent variable and online teaching process as the dependent variable $(\mathrm{H} 3)$ 


\subsection{Data Analysis}

Data analysis was obtained by answering questionnaires provided. Some data deleted because the answers in the questionnaires were empty. The researcher performed demographics analysis, including age, subject of teaching, and gender-data measurement calculated by SPSS vs. 23. Five questions of each dimension were analyzed using the regression for independence in the testing of statistical significance of the relationship between lecturers' adaptability to technological change and its impact on online teaching. Fist to find the reliability and the correlation of data to obtain the next step of the procedure.

Table 1. Descriptive Statistics Reliability and Correlation Among Lecturers' Adaptability, To Technological Change And The Teaching Process

\begin{tabular}{ccccc}
\hline \multirow{2}{*}{ Variables } & \multirow{2}{*}{ Reliability } & \multicolumn{3}{c}{ Correlation } \\
\cline { 3 - 5 } & & $\mathrm{H} 1$ & $\mathrm{H} 2$ & $\mathrm{H} 3$ \\
\hline H1 & 0.823 & 1 & 0.584 & 0.872 \\
H2 & 0.772 & 0.584 & 1 & 0.798 \\
H3 & 0.889 & 0.872 & 0.798 & 1 \\
\hline
\end{tabular}

In descriptive statistics reliability for each item, it found out that $\mathrm{H} 1$ or lecturers' adaptability is 0.823 , which means strong. And $\mathrm{H} 2$ or lecturers to technological change is 0.772 , and it is strong. $\mathrm{H} 3$ or the lecturers' adaptability to technological change and its impact on the teaching process is 0.889 , which is precisely strong. The correlation between $\mathrm{H} 1$ and $\mathrm{H} 2$ is 0.584 ; it is strong enough, $\mathrm{H} 1$ and $\mathrm{H} 3$ are $0.872, \mathrm{H} 2$, and $\mathrm{H} 3$ is 0.798 , which is strong. The data above stated that the questionnaires for lecturers' adaptability to technological change and its impact on the teaching process is valid.

\section{Results}

The research investigated the frequency of each item dimensions from questionnaires. It stated to approve that each frequency is the item to be scored, and it will indicate that the finding and the result of this research.

Table 2. Descriptive Statistics Frequency of Lecturers' Adaptability To The Technological Change And Its Impact On The Teaching Process

\begin{tabular}{lcccc}
\hline \multicolumn{1}{c}{ Variables } & Means & SD & Frequency & Percentage \\
\hline & \multicolumn{1}{c}{ Lecturers Adaptability } & & \\
\hline Improving & 3.53 & 0.704 & 85 & 74.6 \\
\hline Easy life & 3.55 & 0.720 & 83 & 72.8 \\
\hline Belief & 3.37 & 0.797 & 80 & 70.2 \\
\hline Ability and Skillful & 3.59 & 0.698 & 79 & 68.1 \\
\hline Training & 3.49 & 0.666 & 74 & 64.91 \\
\hline \multicolumn{5}{r}{ The Use of Technological Change } \\
\hline Use of technology in teaching & 3.51 & 0.625 & 90 & 78.9 \\
\hline Use the Internet and Social Media & 3.51 & 0.728 & 88 & 77.2 \\
\hline Sharing and contribution the contents & 3.35 & 0.783 & 87 & 76.3 \\
\hline Digital Literacy & 3.47 & 0.839 & 85 & 74.6 \\
\hline Learning from others on the Internet & 3.49 & 0.679 & 82 & 71.9 \\
\hline \multicolumn{7}{r}{ Learning and Teaching Process } \\
\hline Lecturers' Adaptability & 34.56 & 3.802 & 85 & 74.6 \\
\hline The use of technological change & 33.77 & 3.373 & 87 & 76.3 \\
\hline
\end{tabular}


Table 2 indicates that the highest frequency in lecturers' adaptability is improving (85 participants or $74.6 \%$ with means 3.53 dan std. dev. 0.704 ). The highest frequency in using technological change is having equipment such as computers, laptops, or androids (99 participants or $86.84 \%$, means 3.51 and std. dev. 0.625$)$. When the interview conducted, most lecturers stated that they improved their teaching online, and they have tried to improve it because they were afraid that campus would not teach anymore. And as the world infected with COVID-19, the learning process uses virtual learning. All the teaching is online. And the campus has instructed that the learning process is online. Some lecturers moved to online teaching, and others have difficulty, and they only use WhatsApps for the learning process, which WhatsApps is ineffective for a learning process. It is only useful for communication, such as send the message, documents, or video or voice call (Cetinkaya, 2017). The lecturers stated that they would learn the use of distance learning, but they need the time. A tendency that lecturers must be able to improve the learning process is a must because to adapt to technological changes that originate from technology in the classroom and move to virtual technology. There seems to be a significant disruption in this change because of changes in total learning and must be carried out in every learning by lecturers and students (Banks, 2017); ( Bogdan-Martin, 2019). Besides that, Collie \& Martin (2016) stated that adaptability associated with academics shows positively with improving learning. Adaptable lecturers tend to have great incremental beliefs and emotional intelligence that can be forged (Dweck, 2006), and positive attitudes and personalities show all of that. In terms of the use of technology in teaching, most lecturers have already used it, such as PowerPoint, computers, pencils, papers, and others. But only some the lecturers understand to use of advanced technology. And for higher technology in the form of online collaboration and conference tools (Murati \& Ceka, 2017). The latest technology makes it possible to use it in physical and virtual classrooms that were previously impossible. In the interview was done, some lecturers mentioned that like the example that lecturers usually do in an online class when the lecturers give instructions and can be recorded by students or the lecturers themselves directly from their computers without any complicated equipment. According to Bakia, Shear, Toyama, \& Lasseter (2012), the lecturers use technology such as embed PowerPoint and give it to students as teaching material. And lectures like this will be useful if the lecturer provides clear instructions. And this can be repeated several times without having to present lecturers in conferences tailored to student acceleration.

The second highest frequency for lecturers' adaptability is to make the life easy (83 participants or $72.8 \%$ with means 3.55 and the std. dev. 0.720). And the second-highest frequency in the use of technological change is the benefit of using the Internet and social media (88 participants or $77.2 \%$ with means 3.51 and std. dev. 0.728 ). In the interview, most lecturers had mentioned that technology makes life more comfortable and more accessible. Also, in learning, the use of technology provides excellent benefits. According to Desmal (2017), the use of the Internet and social media has increased sharply in the academic world since the introduction of collaborative learning. The impact of the use of social media on academic performance dramatically affects the behavior of lecturers and students, so the campus must choose a website and social media that are appropriate and adequate for learning. In exploring the Internet, it takes technical knowledge and reliable learning resources (Savvidis, 2016). One of the essential features and benefits of technology is a computer program designed for active self-perception and helps students understand knowledge, skills, and abilities. Lecturers must be able to use technology and not be afraid of technology so that learning can be done well (Bray, 2007). The active involvement between technology and learning materials increase the learning process that can be interactive, and student 
involvement becomes feedback that learning is received (Roy, 2019). In the 4.0 Industrial Revolution, many people used the Internet, and the Internet is significantly massive. In using the Internet and social media, lecturers and students must be able to draw emphasis on all fields of science. Ability and skills in literacy, technological literacy, and human literacy must be applied and demonstrated on the Internet and social media (Van Damme, 2016). Hence, lecturers' skills are educational competencies, technology commercialization, and abilities in globalization as well as expertise in future strategies. Besides, lecturers need to have skills and friendliness with technology, collaboration, creativity, and taking risks and teaching holistically. By using an open learning platform, the teacher can skillfully and be able to demonstrate abilities and expertise in advanced technology (Mardiana, 2018).

The third frequency of lecturers' adaptability is the belief (80 participants or 70.2) and the third frequency of using technology in sharing and contributing the content (87 participants or $76.3 \%$ ). From the interview, the lecturers have stated that belief is a must, and it should show in the teaching. The lecturers think that belief is one of the most critical parts of teaching. According to Mofreh \& Ghafar (2018), to improve the professional instruction of lecturers, they must have a belief so that there is a connection between teaching and online teaching practices. The influence of belief is closely related to online teaching. So online learning can run properly. Tio et al. (2008) stated that almost all of the participants indicated that belief is one of the components that the lecturers or educator must-have. According to Bogdan-Martin (2019), belief in technology states that lecturers as facilitators guide students in understanding information. And this relationship can be noted as a student-centered, constructivist approach, and the use of technology is a tool. So belief and technology must provide high innovations in learning. The belief factor is the main factor influencing lecturers in using technology so that constructivist teaching practices can use. In sharing and contributing the contents when the interview had done, lecturers implemented that sharing and providing the contents of learning help the teaching process (Bray, 2007). Especially when they have a discussion online between lecturers, the discussion gives an input of teaching. The material of teaching may discuss before the learning will contribute the online teaching properly. For some points, Killion (2015) revealed that lecturers could encourage students to build their knowledge, work together, and learn to question and evaluate the truth of the learning. Also, Le et al., (2017) stated that with the technology, where learning resources can take from the Internet, contribute and share learning between fellow lecturers, lecturers, and students or between students provides new pedagogical construction and uses technology. This pedagogical construction creates new learning using technology.

The fourth highest frequency of lecturers' adaptability is the ability to be skillful with 79 participants, $68.1 \%$, and means 3.59 and std. dev. 0.698 . The fourth highest frequency of the use of technology is technology literacy, with 85 participants or $74.6 \%$ and means 3.47 and std. dev. 0.839. As the interview had done to the lecturers, the lecturers believe that to teach online classes, the lecturers must have the knowledge and skill of technology. To adapt the ability and skill in online teaching, lecturers must do the presentation and use a video conference that describes the learning. The knowledge and skill of technology have shown when they teach an online class. The researcher Rubio (2016) stated that lecturers' ability to teach would be proven if the learning they manage runs effectively. Lecturers are responsible for student achievements and successes as the profession of lecturers. The lecturer believes that students can learn even though they learn in different ways. McMichael (2018) mentioned that lecturers could motivate and engage students rather than just accepting several students who cannot be involved and are predestined to be left behind. In the interview, the lecturers said that the material delivered must be included in the learning, and students could process 
the material in their brains to be presented later in the online learning process. Students who are missing behind in receiving learning can present after receiving guidance from the lecturer. Su \& Wood (2012) revealed that in online learning, teaching excellence could not be obtained adequately from typologies and descriptions of techniques and skills, but instead was built through the involvement of students in meaningful dialogue about pedagogy. Lecturers must make significant student involvement in the discussion by pedagogy. According to Caskey \& Carpenter (2014), the lecturers must show the cognitive process in teaching online, which can prove by displaying some digital writing techniques online in the form of visual displays, moving images, audio, video, and multimodal forms. Also, lecturers can illustrate digital literacy from various perspectives and are developed in technology so that lecturers are cognitively, socially, and affective of digital literacy because this is a crucial requirement in online education (Banks, 2017). To utilize technology for learning effectively, lecturers need to have a certain level of digital literacy than just knowing how to operate the technology; besides that, it requires proper information management and critical thinking skills and the right online behavior (Chun \& Chaw, 2016). Also, the relationship between active learning and literacy construction, such as the basics, background knowledge, competency centers, and attitudes and perspectives, shows that digital literacy has a close relationship (Bogdan-Martin, 2019).

The fifth or the last frequency of lecturers' adaptability is training, which has 74 participants or 64.91 , which means 3.49 and std. dev. 0.666 . The fifth or last of technology use is learning from others on the Internet, is 82 or $71.9 \%$, means 3.49 and std. dev. 0.679 . Since the training has done to some or all lecturers on campus, the training is essential. When the interview had done, some of the training had run well, but some is challenging to follow. When the lecturers have problems, some of them ask the trainers, but some do not do anything. They seemed to give up and just follow the training to get the certificate. And whenever it times to come to teaching online, they still did the same thing as before the training. With that circumstance of the university, many lecturers who teach at the university do not meet the requirements as they should, even though the members of the university are experts and extensive knowledge and specialization in their fields. The research by Al-Hattami et al. (2013) mentioned that many students have a profound experience taught by skilled and teaching professors. Still, it is ironic that this tendency is considered trivial by universities, so learning is not sufficient. Fry et al., (2009) stated that as the lecturers continued in the $21 \mathrm{st}$ century teaching methods, many campuses realized that they needed teaching skills and immense knowledge and the ability to be relied upon to be integrated into a curriculum that required university members to improve their teaching skills accordingly. Ertmer \& OttenbreitLeftwich (2010) revealed that training of technological capabilities for teaching adjusted to the university's capacity but instead ignored the competencies needed to make the university declared not to meet higher standards education in Indonesia. In the use of technology, learning from others on the Internet will not be ignored. In the interview was conducted, many lecturers were reluctant to learn more from the Internet because of fears of technology and technology illiteracy. So the learning will be interrupted, and the lecturers avoided gaining their knowledge, skills, and abilities. According to Seechaliao (2015), lecturers also believe that social media can be a valuable tool for online and collaborative teaching. Addition students can choose when and where they study, and exchange teaching materials, discuss topics and make their knowledge grow. Learning via the Internet or social media, such as on YouTube, Facebook, blogs, and wikis, apply technology skills in education and everyday life. Therefore lecturers can adopt integrated social media in learning, and also students adopt mixed social media for learning. 
The frequency of lecturers' adaptability to the learning and teaching process is 87 participants or $78.3 \%$ with means of 33.77 and in the learning and teaching process std. dev. 3.373 , and the frequency of the use of technological change is 85 participants or $74.6 \%$ with means 34.56 and std. dev. 3.802. In adopting advanced technology, lecturers must be proactive so that professional learning is more directed. Lecturers must develop their identity and capacity to make decisions about practice rather than being a clone of a particular policy or context (Boyd, 2014). Lecturers must have an idea of learning tools, and lecturers should be encouraged to analyze critical incidents in their learning and criticize them. The key to the continuous professional development of lecturers is to adapt technology (Collie, Martin, \& Granziera, 2018). As in the global pandemic COVID-19, universities pushed to move to online learning, and it can reflect the result of online education by showing lecturers' ability and technological skills and provide feedback and solution in online learning. The lecturers' responsibilities as instructors are in priority, as holders of knowledge who instill wisdom and the students will gain access to experience, and even the learning of the technical skill through a few clicks on their cellphones, tablets, or computers. So the lecturers must be able to facilitate the development of education. In providing the facilities, lecturers must be able to adapt to rapid technological changes and require technological skills ( Ertmer \& OttenbreitLeftwich, Teacher Technology Change: How Knowledge, Confidence, Beliefs, and Culture Intersect, 2010). When the interview had done, some of the lecturers have moved to online learning and comfortable with online teaching. These kinds of lecturers are the lectures that needed in the 21-century learning process. Some lecturers are quite old, but the spirit of teaching online also has the ability and skills to teach online. And some others are just not moving; they stay where they have been. They need motivation and training in teaching online (Alamsyah, 2018). It is apparent differences in learning that some lecturers teach as if they were teaching in class, giving students a lot of assignments. And the task must be completed right away. And this learning cannot be applied in online learning, because the internet connection of each lecturer and student is different. Especially if students are late in entering the system, and they missed the instructions (Banks, 2017).

\section{Discussion}

The result showed that learning by using technology with the right target instructor or online methodology is essential, affordable, engaging, and specialized, therefore lecturers must have the values of abilities and skills of online learning and accompanied by instructors' experiences and independent learning by strengthening patterns think lifelong learning. Online learning must be accompanied by teaching and independent learning experiences by strengthening the mindset of lifelong learning (Fry, Ketteridge , \& Marshall, 2009).

In reality, a belief between theory and technical expertise in the university in which the soft skills are the professional realm. According to the McKinsey Global Institute report in 2017, $50 \%$ of work activities will be automated by 2030 , and machines are better at these skills. But the lecturers' soft skills are competitive advantages, such as leadership, management, online learning, innovation and complex problem solving, creativity and emotional intelligence, and resilience. The period of learning change makes the students and lecturers discover a new way to adapt to the situation, which did not create to exist (Bakia, Shear, Toyama, \& Lasseter, 2012). With improving lecturers' ability in the online learning process, it will build the environmental skills such as making useful materials and involving students in discussion. Without a physical presence in the classroom, lecturers can establish a virtual appearance from the beginning (Christensen \& Horn, 2011). In the interview with some students, the students feel their presence is valued and can also provide lecture rules in an online class at 
each meeting. The involvement of students and lecturers in online learning encourages learning to develop better, and professional relations between lecturers and students become separate experiences for students. As the teaching change, technology has a fundamental structural structure that is an integral part of achieving significant productivity improvements (Murati \& Ceka, 2017). In the time of pandemic COVID-19, most university has pushed the lecturers to teach online, and the university makes sure that the teaching should approach remote area and useful for the students. And lecturers can share the meeting link of the platform or application with students and learning instructions can do afterward. Hence, the lecturers who can adapt to technological changes will continue to teach, and their knowledge, skills, and abilities will increase. Besides, lecturers have peers who can exchange learning content. Technology can facilitate learning and provide convenience for everyone. Learning through technology has become the choice for learning in the 21 st century.

\section{Conclusion}

Online learning is flexible and ensures that learning outcomes achieved, and students can learn without having to miss learning material. Online learning must be provided by the campus so that all learning content and student learning rights fulfilled. Hence, the university offers training and infrastructure so as not to confuse in using technology by lecturers and students. By having the ability and technological skills, lecturers will easily access the information, learning resources and can share knowledge and content with other lecturers. And the university policy to find out what learning is taking place can be done with the agreement between the university, lecturers, and students. And the teaching is done fairly.

It should emphasize that online learning platforms must be used and demonstrated in a learning environment. Online learning that is different from traditional learning must carry out effectively, and it is necessary to involve students in discussions so that learning produces positive outcomes. Moreover, online learning is student-centered lecturers facilitate and make arrangements to ensure students receive learning content and have questions and answers so as not to miss learning. Technology assists lecturers and students by having clear and frequent communication. Learning feedback from students can be consolidated, communicated, and thoroughly discussed so that the effectiveness of online learning, changes in assessment, and self-discipline can achieve. It is essential to check students who have special needs or who are weak to continue to be guided and directed so that they are not missing behind in learning. So that the online learning process can be one of the best learning in the 21 st century.

\section{Reference}

Van Damme, D. (2016). The innovation imperative in education. Educational Research and Innovation. Paris: Secretary-General of the OECD. Retrieved from http://www.oecd.org/education/ceri/GEIS2016-Background-document.pdf

Adit, A. (2020, March 17). Perhatikan $10 \mathrm{Hal}$ Ini Agar Pembelajaran Daring Efektif. (A. Adit, Editor) Retrieved from Kommpas.com: https://www.kompas.com/edu/read/2020/03/17/113921271/perhatikan-10-hal-iniagar-pembelajaran-daring-efektif?page=all

Bakia, M., Shear, L., Toyama, Y., \& Lasseter, A. (2012). Understanding the Implications of Online Learning for Educational Productivity. U.S. Department of Education, Office of Educational Technology. Washington, DC: Center for Technology in Learning SRI International. Retrieved from https://tech.ed.gov/files/2013/10/implications-onlinelearning.pdf 
Bogdan-Martin, D. (2019). Digital Skills Insight. International Telecommunication Union, Telecommunication Development Bureau (TDB). Geneva, Switzerland: International Telecommunication Union. Retrieved February 8, 2020, from https://academy.itu.int/sites/default/files/media2/file/Digital\%20Skills\%20Insights\%20 2019\%20ITU\%20Academy.pdf

Bouthillier, F., \& Shearer, K. (2002, October). Understanding knowledge management and information management: the need for an empirical perspective. Information Research, 8(1), 1-39. Retrieved February 7, 2020, from Askspoke: https://s3.amazonaws.com/academia.edu.documents/34119477/05_05_Understandi ng_IM_and_KM_1.pdf?response-contentdisposition=inline \%3B\%20filename\%3DUnderstanding_knowledge_management_an d_i.pdf\&X-Amz-Algorithm=AWS4-HMAC-SHA256\&X-AmzCredential=AKIAIWOWYYGZ2Y5

Bray, D. A. (2007). Being a Systems Innovator. In R. T. Watson, Information Systems (pp. 415). Idaho, Idaho State, USA: Global Text Project. Retrieved from http://www.uky.edu/ gmswan3/777/IS_Book.pdf

Christensen, C. M., \& Horn, M. B. (2011, October 11). The rise of online education. Retrieved from The Washington Post Daily News: https://www.washingtonpost.com/national/oninnovations/the-rise-of-online-education/2011/09/14/glQA8e2AdL_story.html

Dalkir, K. (2005). Knowledge Management in Theory and Practice. Burlington, MA 01803, USA: Elsevier Butterworth-Heinemann.

Desmal, A. J. (2017, June 28). The impact of using social media and the Internet on academic performance case study Bahrain Universities. EAI Endorsed Transactions on Scalable Information Systems, 4(13), 1-12. DOI:10.4108/eai.28-6-2017.152748

Ertmer, P. A., \& Ottenbreit-Leftwich, A. T. (2010). Teacher Technology Change: How Knowledge, Confidence, Beliefs, and Culture Intersect. Journal of Research on Technology in Education, 42(3), 255-284. Retrieved from https://files.eric.ed.gov/fulltext/EJ882506.pdf

Fry, H., Ketteridge, S., \& Marshall, S. (2009). A user's guide. In H. Fry, S. Ketteridge, \& S. Marshall, A Handbook for Teaching and Learning in Higher Education Enhancing Academic Practice (3rd Edition ed., pp. 3-8). New York, NY, USA: Routledge, Taylor and Francis Group. from https://www.sun.ac.za/english/faculty/arts/Documents/HandbookTeachingLearningHi gheEd.pdf

Gaižiūnienè, L. (2019). Innovative Study Methods Adaptation: The Power of An Effective Teacher. The European Journal of Social and Behavioural Sciences, XXIV, 28772890. DOI:10.15405/ejsbs.251

Hajric, E. (2018). Knowledge Management System and Practices - A Theoretical and Practical Guide for Knowledge Management in Your Organization. Jacksonville, FL, USA: Helpjuice. Retrieved February 8, 2020, from file:///D:/Knowledge\%20Management/Knowledge_Management_A_Theoretical_And_ Practical_Guide_Emil_Hajric(PDF).pdf

Kukulska-Hulme, A. (2012). How should the higher education workforce adapt to advancements in technology for teaching and learning? The Internet and Higher Education, 15(4), 247-254. DOI:10.1016/j.iheduc.2011.12.002 
Lederman, D. (2020, March 25). The Shift to Remote Learning: The Human Element. Retrieved from INSIDE HIGHER ED: https://www.insidehighered.com/digitallearning/article/2020/03/25/how-shift-remote-learning-might-affect-studentsinstructors-and

Lü, L. (2018, July 6). Teacher, Teaching, and Technology: The Changed and Unchanged. International Education Studies, 11(8), 39-47. DOI:10.5539/ies.v11n8p39

Matas, C. P., \& Cameron, A. (2005). Providing feedback to online students: A new approach. HERDSA 2005 conference (pp. 389-398). Griffith: HERDSA. Retrieved from https://www.researchgate.net/publication/29453785_Providing_feedback_to_online_s tudents_A_new_approach

Pionke, R. (2018, September 7). Three Keys to Keeping Pace with Technology Changes in Academia. Retrieved from The Evolution - A Density Solution Illumination: https://evolllution.com/technology/tech-tools-and-resources/three-keys-to-keepingpace-with-technology-changes-in-academia/

Roblyer, M. D., Porter, M., \& Bielefeldt, T. (2009). "Teaching Online Made Me a Better Teacher": Studying the Impact of Virtual Course Experiences on Teachers' Face-toFace Practice. Journal of Computing in Teacher Education, 25(4), 121-126. Retrieved from https://files.eric.ed.gov/fulltext/EJ844209.pdf

Roy, A. (2019). Technology in Teaching and Learning. Journal of Emerging Technologies and Innovative Research (JETIR), 6(4), 356-362. Doi: 10.31686/ijier.Vol7.Iss4.1433

Rubio, C. M. (2009). EFFECTIVE TEACHERS -PROFESSIONAL AND PROFESSIONAL AND. ENSAYOS. Revista de la Facultad de Educación de Albacete, 24, 35-46.

Seechaliao, T. (2015). Lecturers' Experience Of Using Social Media In Higher Education Courses. Contemporary Issues In Education Research - 4th Quarter, 8(4), 215-222. Retrieved from https://files.eric.ed.gov/fulltext/EJ1077332.pdf

South, J., \& Stevens, K. (2017). Reimagining the Role of Technology in Education: 2017 National Education Technology Plan Update. Office of Educational Technology, U.S. Department of Education. Washington, D.C.: NETP Development - American Institutes for Research. Retrieved from https://tech.ed.gov/files/2017/01/NETP17.pdf

Wright, V. H., \& Wilson, E. K. (2011). Teachers' Use of Technology: Lessons Learned from the Teacher Education Program to the Classroom. SRATE Journal, 20(2), 48-60. Retrieved from https://files.eric.ed.gov/fulltext/EJ959529.pdf

Alamsyah, A. (2018). Analyzing the change of students' attitudes toward learning English (A case study of foreign language school). International Conference on Life, Innovation, Change, and Knowledge (ICLICK, 2018). 203, pp. 134-140. Atlantis Press - Advances in Social Science, Education, and Humanities Research. Retrieved from Atlantispress.com

Al-Hattami, A., Muammar, O. M., \& Elmahdi, I. (2013). The need for professional training programs to improve faculty members teaching skills. European Journal of Research on Education, 1(2), 39-45. Retrieved from https://www.researchgate.net/publication/268077040_The_need_for_professional_tra ining_programs_to_improve_faculty_members_teaching_skills

Banks, K. L. (2017). Technological Changes in Education: How Teachers Can Adapt. Retrieved from Bright Hub Education: https://www.brighthubeducation.com/teachingmethods-tips/106543-21st-century-technological-changes-in-education/

Bergmann, S., \& Brough, J. A. (2007). Lead me. I dare you! : Managing Resistance to School Change. Larchmont, NY: Eye on Education. Retrieved from Eye On Education. 
Boyd, P. (2014). Learning Teaching in School. In H. Cooper, \& H. Cooper (Ed.), Professional Studies in Primary Education (2nd ed., pp. 267-288). London, London, United Kingdom: SAGE Publication. Retrieved from http://insight.cumbria.ac.uk/id/eprint/1623/1/61142_Cooper.pdf

Caskey, M. M., \& Carpenter, J. (2014, October). Building Teacher Collaboration School-wide. (A. Magazine, Producer) Retrieved from Association for Middle-Level Education (AMLE):

https://www.amle.org/BrowsebyTopic/WhatsNew/WNDet/Tabld/270/ArtMID/888/Articl elD/446/Building-Teacher-Collaboration-School-wide.aspx

Cetinkaya, L. (2017, November). The Impact of Whatsapp Use on Success in Education Process. International Review of Research in Open and Distance Learning, 18(7), 5974. DOI:10.19173/irrodl.v18i7.3279

Chapman, D. W.; Garett, Amy; Mählck, L. O.. (2004). The Role of Technology in School Improvement. In D. Chapman, \& L. O. Mahlck, Adapting Technology for School Improvement: A Global Perspective (pp. 39-54). Paris, France, France: UNESCO.

Chun, M. T., \& Chaw, L. Y. (2016). Digital Literacy: A Prerequisite for Effective Learning in a Blended. The Electronic Journal of e-Learning, 14(1), 54-65. Retrieved from https://files.eric.ed.gov/fulltext/EJ1099109.pdf

Cohen, A., Fetters, M., \& Fleischmann, F. (2005). Significant change at Babson College: Curricular and Administrative, Planned, and Otherwise. Advance in Developing Human Resources, 7(3). DOI:10.1177/1523422305277173.

Collie, R. J., \& Martin, A. J. (2016). Adaptability: An important capacity for effective teachers. Educational Practice and Theory, 38(1), 27-39. DOI:10.7459/ept/38.1.03.

Collie, R. J., Martin, A. J., \& Granziera, H. (2018, May 18). Being able to adapt in the classroom improves teachers' well-being. Retrieved from The Conversation: https://theconversation.com/being-able-to-adapt-in-the-classroom-improvesteachers-well-being-95788

Cresswell, J. W. (2014). Research Design: Qualitative, Quantitative, and Mixed Method Approaches (4th Edition ed.). (V. Knight, Ed.) Thousand Oak, California, USA: SAGE Publication, Inc. Retrieved January 31, 2020, from http://fe.unj.ac.id/wpcontent/uploads/2019/08/Research-Design_Qualitative-Quantitative-and-MixedMethods-Approaches.pdf

Dweck, C. S. (2006). Mindset: the new psychology of success. New York, NY: Random House.

Ertmer, P. A., \& Ottenbreit-Leftwich, A. T. (2010). Teacher Technology Change: How Knowledge, Confidence, Beliefs, and Culture Intersect. Journal of Research on Technology in Education, 42(3), 255-284. Retrieved from https://files.eric.ed.gov/fulltext/EJ882506.pdf

Groff, J. (2013). Technology-Rich, Innovative Learning Environments. OECD. Retrieved from http://www.oecd.org/education/ceri/technologyrich\%20innovative\%20learning\%20environments\%20by\%20jennifer\%20groff.pdf

Hamiti, M., \& Reka, B. (2012, December). Teaching with Technology. Procedia - Social and Behavioral Sciences, 46, 1171-1176. DOI:10.1016/j.sbspro.2012.05.269

Hayes, H. B. (2017, July 5). Advances in Technology Foster Collaboration Between Students and Teachers. Retrieved April 22, 2020, from Ed Tech Focus on K-12: https://edtechmagazine.com/k12/article/2017/07/advances-technology-fostercollaboration-between-students-and-teachers 
Howard, S. K., \& Mozejko, A. (2015). Teachers: technology, change, and resistance. In M. Henderson, G. Romeo, M. Henderson, \& G. Romeo (Eds.), Teaching and Digital Technologies: Big Issues and Critical Questions (pp. 307-317). Port Melbourne, Australia, Melbourne, Australia: Cambridge University Press. Retrieved from https://www.researchgate.net/publication/292971267_Teachers_technology_change and_resistance

Killion, J. (2015). High-quality collaboration benefits teachers and students. JSD | www.learningforward.org. Retrieved from https://learningforward.org/wpcontent/uploads/2015/10/high-quality-collaboration-benefits-teachers-andstudents.pdf

Lase, D. (2019). Education and Industrial Revolution 4.0. Nias: STT Banua Niha Keriso Protestant Sundermann Nias. DOI:10.24114/jh.v10i1

Le, H., Janssen, J., \& Wubbels, T. (2017, January 13). Collaborative learning practices: teacher and student perceived obstacles to effective student collaboration. Cambridge Journal of Education, 48(1), 103-122. DOI:10.1080/0305764X.2016.1259389

Mählck, L. O., \& Chapman, D. W. (2004). Chapter 14: Effective Use of Technology to Improve Education: Lesson for Planners. In L. O. Mählck, \& D. W. Chapman, Adapting Technology for School Improvement: A Global Perspective (p. 298). Paris: International for Education Planning.

Mardiana, H. (2018, March). Lecturer's Attitude towards Advance Technology and Its Impact on the Learning Process: A case study in Tangerang City Campuses. Journal of Educational Science and Technology, 4(1), 12-25. doi:http://dx.doi.org/10.26858/est.v4i1.4974

McKinsey \& Company. (2017). Jobs Lost, Jobs Gained: Workforce Transactions in a Time of Automation. McKinsey Global Institute. New York: www.mckinsey.com/mgi. Retrieved from

https://www.mckinsey.com/ /media/mckinsey/featured\%20insights/Future\%20of\%20 Organizations/What\%20the\%20future\%20of\%20work\%20will\%20mean\%20for\%20jo bs\%20skills\%20and\%20wages/MGI-Jobs-Lost-Jobs-Gained-Report-December-62017.ashx

McMichael, M. (2018, May 16). What is Technological Adaptability? Retrieved from Technoadaptability: http://www.technodaptability.com/

Mofreh, S., \& Ghafar, M. N. (2018). The Influences of the Lecturers' Beliefs on Teaching Functions on Teaching Practices. Proceedings of the 4th ASEAN Conference on Psychology, Counselling, and Humanities (ACPCH 2018). 304, pp. 462-466. advances in Social Science, Education, and Humanities Research (ASSEHR) - Atlantis Press. DOI:10.2991/acpch-18.2019.107

Murati, R., \& Ceka, A. (2017). The Use of Technology in Educational Teaching. Journal of Education and Practice, 8(6), 197-199. Retrieved from https://files.eric.ed.gov/fulltext/EJ1133000.pdf

Rice, K. (2006). A Comprehensive Look at Virtual Education in the K-12 Context. Journal of Research on Technology in Education, 38(4), 425-448. DOI:10.1080/15391523.2006.10782468

Savvidis, P. (2016, 2). Top 6 benefits of using technology in the classroom. Retrieved from Webanywhere Stretch Beyond: https://www.webanywhere.co.uk/blog/2016/02/top-6benefits-technology-classroom/ 
Soegiono, N. A. (2019, October 28). Nadiem: Driving education reform through technology. Retrieved from Jakarta Post:

https://www.thejakartapost.com/academia/2019/10/28/nadiem-driving-educationreform-through-technology.html

Su, F., \& Wood, M. (2012). What makes a good university lecturer? Students' perceptions of teaching excellence. Journal of Applied Research in Higher Education, 4(2), 142-155. DOI: $10.1108 / 17581181211273110$

The Scottish Government. (2015). Literature Review on the Impact of Digital Technology on Learning and Teaching. Social Research. Edinburgh: the Scottish Government. Retrieved from https://dera.ioe.ac.uk/24843/1/00489224.pdf

Tio, T., Chai, C. S., Hung, D., \& Lee, C. B. (2008, May). Beliefs about teaching and uses of technology among pre-service teachers. Asia-Pacific Journal of Teacher Education, 36(2), 163-174. DOI:10.1080/13598660801971641

UNESCO. (2017). International Literacy Day. Paris: UNESCO. Retrieved from https://en.unesco.org/sites/default/files/ild-2017-summary_of_discussions-en.pdf 